\title{
Degree of risk for foot ulcer due to diabetes: nursing assessment
}

\author{
Grau de risco para úlceras nos pés por diabetes: avaliação de enfermagem \\ Grado de riesgo para las úlceras en los pies por diabetes: evaluación de enfermería
}

\section{Maria do Livramento Saraiva Lucoveis', Mônica Antar Gamba', Maria Angela Boccara de Paula", Ana Beatriz Pinto da Silva Morita"'I}

\author{
' Universidade Federal de São Paulo. São Paulo, São Paulo, Brazil. \\ " Universidade de Taubaté. Taubaté, São Paulo, Brazil. \\ "' Centro Universitario Teresa D'Ávila. Lorena, São Paulo, Brazil.
}

How to cite this article:

Lucoveis MLS, Gamba MA, Paula MAB, Morita ABPS. Degree of risk for foot ulcer due to diabetes: nursing assessment. Rev Bras Enferm [Internet]. 2018;71(6):3041-7. DOI: http://dx.doi.org/10.1590/0034-7167-2017-0189

\author{
Submission: 04-01-2017 Approval: 05-01-2018
}

\begin{abstract}
Objective: To classify the level of risk for foot ulcers in people with diabetes mellitus and identify their main predictive risk factors. Method: Exploratory, descriptive study, in which patients were assessed in a municipal ambulatory of São Paulo through nursing consultation, following the guidelines of the International Consensus on the Diabetic Foot. Data were descriptively analyzed. Results: The analyzed population was composed of 50 longevous and retired people, with household income of up to two minimum wages, with dermatoneurofunctional risk factors and unfavorable clinical indicators, and $66 \%$ had Risk $1 ; 16 \%$ Risk $2 ; 6 \%$ Risk 3 and $12 \%$ Risk 4 . Of this analyzed total, $96 \%$ never had their feet examined with the Semmes-Weinstein monofilament. Conclusion: The data found indicate the importance of careful feet examination in people with diabetes by the nursing staff to identify future risks of ulcers and, thus, prevent them. Descriptors: Diabetes Mellitus; Diabetic Neuropathies; Diabetic Foot; Mass Screening; Nursing.
\end{abstract}

\section{RESUMO}

Objetivo: Classificar o grau de risco para ulcerações nos pés de pessoas com diabetes mellitus e identificar seus principais fatores de risco preditivos. Método: Estudo exploratório, descritivo, onde os pacientes foram avaliados em um ambulatório municipal de São Paulo por meio da consulta de enfermagem, segundo diretrizes do International Consensus on the Diabetic Foot. Os dados foram analisados descritivamente. Resultados: a população analisada foi de 50 pessoas, longevos jovens, aposentados, renda familiar de até dois salários mínimos, com fatores de risco dermato-neuro-funcionais e indicadores clínicos desfavoráveis, sendo que $66 \%$ apresentaram risco 1; 16\% risco 2; 6\% risco 3 e 12\% risco 4 . Dentre estes, $96 \%$ nunca tiveram seus pés examinados com o monofilamento de Semmes Weinstein. Conclusão: Os dados encontrados apontam a importância da avaliação criteriosa dos pés das pessoas com diabetes pela enfermagem para identificar os riscos futuros de ulcerações, e desta forma trabalhar a prevenção dos mesmos.

Descritores: Diabetes Mellitus; Neuropatias Diabéticas; Pé Diabético; Rastreamento; Enfermagem.

\section{RESUMEN}

Objetivo: Clasificar el grado de riesgo para las ulceraciones en los pies de las personas con diabetes mellitus e identificar sus principales factores de riesgo predictivos. Método: Estudio exploratorio, descriptivo, en el cual los pacientes fueron evaluados en un ambulatorio municipal de São Paulo por medio de la consulta de enfermería, según las directrices del International Consensus on the Diabetic Foot. Los datos fueron analizados descriptivamente. Resultados: La población analizada fue de 50 personas, longevos jóvenes, jubilados, con ingresos familiares de hasta dos salarios mínimos, con factores de riesgo dermatoneurofuncionales e indicadores clínicos desfavorables, siendo que el $66 \%$ presentó riesgo 1; el $16 \%$ de riesgo 2; el $6 \%$ riesgo 3 ; y el $12 \%$ de riesgo 4 . De ese total analizado, el $96 \%$ nunca tuvo los pies examinados con el monofilamento de SemmesWeinstein. Conclusión: Los datos encontrados apuntan la importancia de la evaluación cuidadosa de los pies de las personas con diabetes por la enfermería para identificar los riesgos futuros de ulceraciones y, de esta forma, prevenirlos.

Descriptores: Diabetes Mellitus; Neuropatías Diabéticas; Pie Diabético; Tamizaje Masivo; Enfermería. 


\section{INTRODUCTION}

Currently, 415 million people have diabetes mellitus (DM) with worldwide prevalence of $8.8 \%$. By 2040 , it is predicted that about 227 million people will have developed new cases of the disease. The impact was such that, in 2015, 5 million deaths by DM occurred, which implies saying there was a death every six seconds ${ }^{(1)}$.

Brazil is the fourth country with the largest number of people with DM in the world. It is estimated that, currently, 14.3 milIion Brazilians have the disease ${ }^{(1)}$. This scenario asks for urgent measures to control and prevent DM, as well as its complications, otherwise, the country is bound to have a significant number of people with severe sequelae and with reduced life expectancy by the high rate of mortality caused by the disease ${ }^{(2)}$.

Chronic hyperglycemia, due to poorly controlled or late diagnosed DM, is consistent with the progressive degeneration of nervous fibers that affects the integrity of sensory, motor and/ or autonomic nerves, causing reduction in neurological activity, or even its destruction ${ }^{(3)}$.

Among the possible complications from chronic hyperglycemia, diabetic polyneuropathy (DNP) stands out, which can affect people with DM in up to $30 \%$ of cases. It is one of the most common complications inherent to long-term progression $\mathrm{DM}$, with the aggravation of inadequate glycemic control ${ }^{(3-5)}$.

DNP can be considered a precursor in the development of foot ulcers in people with DM, since, once installed, it is responsible for alterations in the protective sensitivity of the feet, and can make them insensitive to painful, pressure, thermal and tactile stimuli. In addition, it can also cause musculoskeletal disorders and alterations in skin integrity ${ }^{(5)}$.

In this sense, people with DM and DNP have great potential for the appearance of foot ulcers, which can lead to the amputation of a limb or part of it. It is estimated that up to $70 \%$ of the amputations in non-traumatic lower extremities result from diabetes, and $85 \%$ of these were preceded by an ulcer that was not avoided ${ }^{(6-7)}$.

The training of the interdisciplinary team is consensual and mandatory for the management of people with DM, including foot management ${ }^{(6-7)}$. The nurse has a fundamental role within this group, acting in order to identify risk factors that lead to complications, to develop educational programs, interventions and continuous monitoring ${ }^{(8)}$.

Nursing consultation is a private activity of the nurse and must be performed to identify with high accuracy people with DM that pose a risk of ulceration ${ }^{(8)}$. In this way, the thorough evaluation of the feet is a critical step in tracking the risk of complications in these limbs. When performing the consultation, the nurse must seek to identify, through a rigorous inspection and palpation, dermatologic, musculoskeletal, vascular and neurological alterations ${ }^{(8-9)}$.

To detect dermatologic alterations, the nurse must investigate the presence of thickened skin (keratosis), calluses, cracks, dry skin, blisters, active ulcer, nail alterations and/or macerations/ interdigital fissures.

In the musculoskeletal evaluation, they must investigate the presence of hallux valgus, claw or hammer toes, overlapping toes, hallux rigidus and decreased mobility, areas of plantar hyper pressure, changes in the curvature of the feet, Charcot foot, intrinsic muscle atrophy evidenced by apparent tendons, which occur due to diabetic neuropathy ${ }^{(9,11)}$.

To identify possible vascular alterations, it is important to inspect the skin, which might be atrophic and shiny, with hairs diminished or absent, cold extremities, thick and involute nails. The LL (lower limbs) may present pallor at elevation and declivity flushing. The presence of intermittent claudication or pain at rest, tibial and feet pulses decreased or absent to palpation suggest Peripheral Artery Disease (PAD) ${ }^{(9,11)}$. The suspicion of PAD may be confirmed by calculating the Ankle-Brachial Index (ABI), which presents values that confirm or discard the presence of PAD; values below 0.9 suggest ischemia, between 1.0 and 1.3 suggest normalcy, and above 1.3 suggest noncompressible arteries $^{(7)}$.

To detect neurological changes, some tests already validated to identify the risk of future injury should be conducted. Among the listed tests, these stands out: to assess vibratory, pain and protective sensitivity through examination with Semmes-Weinstein $5.0710 \mathrm{~g}$ monofilament, as indicative of populational risk screening, in addition to Achilles tendon reflex ${ }^{(9,11)}$.

After thorough examination of the feet, the classification of the detected risk must be performed, through scores, which ranges from low risk to high risk. In addition to point out the risk score for ulcerations, the risk classification system allows to define the frequency of follow-ups and feet evaluation ${ }^{(6-7,9,12)}$.

\section{OBJECTIVE}

To classify the level of risk for foot ulcers in people with diabetes mellitus and identify their main predictive risk factors.

\section{METHOD}

\section{Ethical aspects}

The study was approved by the Research Ethics Committee of the University of Taubaté. Data collection was performed after approval on the Ethics Committee and upon the consent of the participants through signing the Informed Consent Form (ICF).

\section{Study design, location, and period}

Exploratory-descriptive study with quantitative approach. The research was performed in a Specialty Outpatient Clinic from São Paulo City Hall in the southern region. Data were collected from November to December 2013.

\section{Population: inclusion and exclusion criteria}

The study population was composed of 50 individuals who agreed to participate of the study and who fit in the following inclusion criteria: confirmed diagnosis of DM for more than five years, aged 18 years or more, being treated in the specialty of Endocrinology and/or in the Proibido Feridas, a program created by the Municipal Secretary of Health staff to treat people with chronic ulcers and diabetic foot. Individuals who were bilaterally amputated and those who were attending the outpatient clinic for the first time, because they did not have a confirmed diagnosis of DM. 


\section{Study protocol}

For the nursing consultation, a form was used, based on the guidelines of the International Consensus on the Diabetic Foot and the protocol of the Prohibited Wounds program, containing questions on sociodemographic variables and risk factors related to DM, life style and precursors signs of foot ulcerations, and non-invasive neurological tests, collected during the physical exam, which were asked to the study participants and written by the interviewer.

To perform the tests, a monofilament was used (SemmesWeinstein 10g), chopsticks with blunt and pointy tips, 128 Hertz turning fork and neurological hammer to assess the protective, pain and vibratory sensitivity and the Achilles tendon reflex, respectively.

The degree of risk classification of the participants was performed according to Chart 1 , and the following criteria were adopted.

Chart 1 - Classification system for risk of foot ulcerations in people with diabetes mellitus

\begin{tabular}{|c|l|l|}
\hline Degree & \multicolumn{1}{|c|}{ Risk } & \multicolumn{1}{c|}{ Return frequency } \\
\hline 1 & Absent LOPS & Once a year \\
\hline 2 & Present LOPS & Once every 6 months \\
\hline 3 & $\begin{array}{l}\text { LOPS, signs of } \\
\text { peripherical vascular } \\
\text { disease and/or foot } \\
\text { deformity }\end{array}$ & Once every 3 months \\
\hline 4 & Previous ulcer & Once every 1-3 months \\
\hline
\end{tabular}

Source: Adapted from the International Consensus on the Diabetic Foot and from the Guidelines of the Brazilian Society of Diabetes

Note: $L O P S=$ loss of protective sensitivity.

It is worth to emphasize that the objective of this study was to assess the degree of risk for foot ulcerations in people with DM trough LOPS investigation, and not through neuropathy investigation, which is researched upon other scores. On the above, the applied tests proposed to only research LOPS. Thus, in the chart above, the risk factor neuropathy was replaced by LOPS, based on recommendations from the guidelines of the Brazilian Society of Diabetes that guides risk screening considering the LOPS, and not the neuropathy ${ }^{(12)}$.

Therefore, the LOPS was considered absent when the individual was sensitive to the monofilament in the four sites tested. LOPS was considered present when the individual had altered monofilament in one of more tested sites, associated to one or more of the altered tests described above ${ }^{(6)}$.

Pedis and posterior tibial pulses that were absent or difficult to palpate in the same laterality were considered a sign of PAD, because, if these pulses are present, it is unlikely that the PAD is installed in a way to cause hemodynamic repercussions ${ }^{(6)}$. However, the last guidelines guide the calculation of the $A B I$ to confirm or rule out PAD regardless of whether the pedis pulses are present on palpation or not $t^{(7)}$.

The presence of claw or hammer toes, overlapped toes, bony prominences, increase or decrease of plantar arches and/or Charcot feet were considered foot deformities ${ }^{(9)}$.

The history of previous ulcerations and/or amputation was obtained through the individuals' reporting and inspection of lower limbs during the specific feet examination ${ }^{(7-9)}$.
Before the specific examination of the feet and neurological tests, all individuals were properly oriented and positioned in a stretcher, the procedure was demonstrated, so they could interpret the stimuli that they should feel or not when having their feet examined. They were requested to keep their eyes closed during the exam to avoid erroneous results. The places selected to apply the monofilament were: the head of the first, third and fifth metatarsal and of the posterior distal phalanx of the hallux. The monofilament was applied perpendicular to the skin hard enough to bend it, for no more than two seconds. Of the points to be tested had ulcerations and/or calluses, the monofilament was applied around the injuries, so that there were no alterations in the result of the test. While applying the monofilament, the individuals were asked if they felt the applied pressure and which limb was being tested. The monofilament was applied twice in the same place, alternated with a random simulated application, totaling three questions per application site ${ }^{(6-7)}$.

To test pain sensitivity, the chopsticks were used, one with a blunt tip and other with a pointy tip, and the individual should identify when the stimulus was being conducted with the blunt tip or with the pointy tip. The extremities of the chopstick were applied on the back of the hallux with enough pressure to deform the skin without penetrating it. Pain sensitivity was considered preserved when the individual could differentiate the extremities of the chopsticks and, when they could not identify it, it was considered altered/absent ${ }^{(13)}$.

To test vibratory sensitivity, the examination held the tuning fork by the handle and stroke the distal extremity of the object in the palm of the opposite hand so that the instrument would vibrate, then, the handle was placed perpendicular to the bone of the anterior region of the distal phalanx, with constant pressure. The test was performed three times, one of them simulated. The test was considered positive when the individual showed sensitivity to the vibration of the object at least twice out of three attempts ${ }^{(6-7)}$.

To test the reflex of the Achilles tendon, the individual was positioned sitting on the stretcher with the legs hanging. The examiner performed a discrete foot dorsiflexion and stroke the Achilles tendon insertion with the flat part of the neurological hammer. The test was considered positive when the individual performed plantar flexion, and negative when there was no movement ${ }^{(14)}$.

\section{Analysis of the results}

The results were obtained through a descriptive analysis with tables of distribution and simple frequency of discrete values in absolute and percentage numbers, obtained through databases of Microsoft Excel spreadsheets powered by double tying of the variables.

\section{RESULTS}

Data from Table 1 indicate the sociodemographic variables of people with type $2 \mathrm{DM}$, treated in the secondary level of care, with disease duration greater than ten years, mostly female $(64 \%)$, longevous aged from 60 to 69 years $(40 \%)$, with a partner $(52 \%)$, employed $(78 \%)$, and most of the participants $(48 \%)$ had a household income that did not exceeded one minimum wage. Regarding schooling, $24 \%$ were illiterate and $60 \%$ presented up to eight years of study. 
Table 1 - Characterization of patients with diabetes mellitus, treated in a municipal outpatient clinic according to sociodemographic variables, São Paulo, Brazil, $2013(N=50)$

\begin{tabular}{|c|c|c|}
\hline & $\mathbf{n}$ & $\%$ \\
\hline \multicolumn{3}{|l|}{ Gender } \\
\hline Male & 18 & 36 \\
\hline Female & 32 & 64 \\
\hline \multicolumn{3}{|l|}{ Age } \\
\hline $30-39$ & 2 & 4 \\
\hline $40-49$ & 6 & 12 \\
\hline $50-59$ & 17 & 34 \\
\hline $60-69$ & 20 & 40 \\
\hline $70-79$ & 4 & 8 \\
\hline $80-90$ & 1 & 2 \\
\hline \multicolumn{3}{|l|}{ Marital status } \\
\hline Living with a partner & 26 & 52 \\
\hline Living without a partner & 24 & 48 \\
\hline \multicolumn{3}{|l|}{ Professional status } \\
\hline Retired & 17 & 34 \\
\hline Employed & 11 & 22 \\
\hline Unemployed & 17 & 34 \\
\hline Pensioner & 5 & 10 \\
\hline \multicolumn{3}{|l|}{ Household income } \\
\hline Up to 1 minimum wage & 24 & 48 \\
\hline Up to 2 minimum wages & 12 & 24 \\
\hline 2 minimum wages or more & 14 & 28 \\
\hline \multicolumn{3}{|l|}{ Education level } \\
\hline Illiterate & 12 & 24 \\
\hline Up to 8 years of study & 30 & 60 \\
\hline High school & 6 & 12 \\
\hline Higher education & 2 & 4 \\
\hline \multicolumn{3}{|l|}{ Color/Race } \\
\hline Black & 6 & 12 \\
\hline Brown & 22 & 44 \\
\hline Indigenous & 1 & 2 \\
\hline Yellow (Asian) & 1 & 2 \\
\hline White & 20 & 40 \\
\hline
\end{tabular}

Source: Instrument of nursing consultation of the study.

Table 2 shows data that identify the risk factors for foot ulceration related to clinical variables and to signs detected in the specific feet examination. Regarding the control of DM through monitoring glycated hemoglobin, the majority $(62 \%)$ mentioned not knowing this exam as well as its purpose. Among the associated comorbidities, systemic arterial hypertension was the most prevalent with $92 \%$. It was observed that the majority of the participants $(74 \%)$ did not practice any type of physical activity regularly, and $74 \%$ had never received guidance from a health professional about foot care. Regarding the use of adequate footwear, $100 \%$ declared to use common shoes. As for skin hydration, the majority ( $84 \%$ ) had dry skin, and when they were questioned if they would inspect their feet regularly, $48 \%$ said no. Concerning the presence of dermatological alterations, $78 \%$ of the participants had calluses, and $22 \%$ had motor deformities.
Table 2 - Distribution of patients with diabetes mellitus, treated in a municipal outpatient clinic, according to clinical variables and related to the specific feet examination, São Paulo, Brazil, $2013(N=50)$

\begin{tabular}{|c|c|c|}
\hline & $\mathbf{n}$ & $\%$ \\
\hline \multicolumn{3}{|c|}{$\begin{array}{l}\text { Control of DM with glycated hemoglobin } \\
\text { monitoring }\end{array}$} \\
\hline Yes & 17 & 34 \\
\hline No & 2 & 4 \\
\hline Unaware of the examination & 31 & 62 \\
\hline \multicolumn{3}{|l|}{ Systemic arterial hypertension } \\
\hline Yes & 46 & 92 \\
\hline No & 4 & 8 \\
\hline \multicolumn{3}{|l|}{ Dyslipidemias } \\
\hline Yes & 32 & 64 \\
\hline No & 18 & 36 \\
\hline \multicolumn{3}{|c|}{ Regularly performs physical activity } \\
\hline Yes & 13 & 26 \\
\hline No & 37 & 74 \\
\hline \multicolumn{3}{|c|}{$\begin{array}{l}\text { Received guidelines for self-care of the feet } \\
\text { after the diagnosis of diabetes }\end{array}$} \\
\hline Yes & 13 & 26 \\
\hline No & 37 & 74 \\
\hline \multicolumn{3}{|l|}{ Type of footwear } \\
\hline Common & 50 & 100 \\
\hline Special & 00 & 00 \\
\hline \multicolumn{3}{|l|}{ Dry skin } \\
\hline Yes & 42 & 84 \\
\hline No & 8 & 16 \\
\hline \multicolumn{3}{|l|}{ Active ulcer } \\
\hline Yes & 6 & 12 \\
\hline No & 44 & 88 \\
\hline \multicolumn{3}{|l|}{ Inspects their feet regularly } \\
\hline Yes & 16 & 32 \\
\hline No & 24 & 48 \\
\hline Sometimes & 10 & 20 \\
\hline \multicolumn{3}{|l|}{ Callus and callosities } \\
\hline Yes & 39 & 78 \\
\hline No & 11 & 22 \\
\hline \multicolumn{3}{|c|}{$\begin{array}{l}\text { Motor deformities (hallux valgus, overlapped toes, } \\
\text { claw/hammer toes, plantar arch accentuated or } \\
\text { diminished, Charcot foot) }\end{array}$} \\
\hline Yes & 11 & 22 \\
\hline No & 39 & 78 \\
\hline
\end{tabular}

Source: Instrument of nursing consultation of the study. Note: $D M=$ Diabetes Mellitus.

Table 3 - Degree of risk classification for foot ulcers, according to the International Consensus on the Diabetic Foot, São Paulo, Brazil, $2013(\mathrm{~N}=50)$

\begin{tabular}{lcc}
\hline \multicolumn{1}{c}{ Risk classification } & $\mathbf{n}$ & $\mathbf{\%}$ \\
\hline Risk 1 & 33 & 66 \\
Risk 2 & 8 & 16 \\
Risk 3 & 3 & 6 \\
Risk 4 & 6 & 12 \\
Total & 50 & 100 \\
\hline
\end{tabular}

Source: Instrument of nursing consultation of the study. 
Regarding the classification of foot ulcers, it is possible to verify, in Table 3, the already installed presence of factors predisposing to ulceration, because the following was identified: $66 \%$ with degree of risk $1,16 \%$ degree $2,6 \%$ degree 3 , e $12 \%$ degree of risk 4 .

\section{DISCUSSION}

In this research, the literature on the topic in question corroborates the predominance of feminization that can be justified by the fact that, still, women seek health services more often than men, with well discussed findings in studies on morbidity ${ }^{(15-16)}$.

As for age, prevalence studies support the manifestation of type 2 DM in young adults, in which half the people with the disease have from 40 to 59 years-old ${ }^{(2)}$. It is worth noting that this age group includes people who are in a productive phase to exercise remunerated activity, but, due to DM complications, they leave their activities, suffering emotional and economic losses. In addition, the economic burden of these complications such as absenteeism at work, medical licenses, missing work for medical consultations, low productivity, rehabilitation and early retirements are problematic for the Health System ${ }^{(2-6)}$.

The variable "household income" detected social vulnerability in this group, in which most survived with up to two minimum wages, that is, those that are socially and economically disadvantaged. A study points out that up to $80 \%$ of individuals with diabetes live in low-income countries, demonstrating the magnitude of the problem in this social stratum ${ }^{(2)}$.

With regard to education level, low schooling was detected, including illiterates. In a study with the objective of characterizing individuals with type 2 DM registered in a Basic Health Unit in the city of Porto Alegre, RS, it was identified that $18.4 \%$ were illiterate and $74.4 \%$ had up to eight years of study ${ }^{(16)}$. These data confirm the socioeconomic and intellectual fragility of great part of the affected, demonstrating the importance of considering the level of potentiation for self-care of this population in prevention and education problems.

Clinical analysis related to the control of the disease, obtained through glycated hemoglobin counting, determined that $66 \%$ reported not knowing the exam, or did not perform it. Glycated hemoglobin count is one of the main ways of glycemic control, and, according to the guidelines of the Brazilian Society of Diabetes, it must be requested routinely for all individuals with DM every three months, however, health professionals must determine the periodicity individually, according to the clinical conditions of the individual and the aimed glycemic target ${ }^{(12)}$.

Associated comorbidities, such as systemic arterial hypertension and dyslipidemia, were the most mentioned. Individuals with DM showed cardiovascular risk twice or four times higher when compared with people without the disease, which demonstrates the importance of the treatment and control of these comorbidities $^{(17)}$.

Concerning the practice of physical activity, only a minority referred to regular practice. The practice of aerobic exercises is recommended, such as walking, dancing, swimming, running and cycling, at intervals of three to five times per week, lasting 30 to 60 minutes. Physical exercise provides the body with better control of glycemic levels, including reduction of glycated hemoglobin and cardiovascular risks, in addition to contributing for weight reduction and raising self-esteem ${ }^{(12)}$.

Most of the participants never received orientations from a health professional about foot care. Educating these individuals is still a challenge for health professionals, either for the lack of scientific knowledge, time in light of several assignments, or even if it was not effectively performed. In this sense, we highlight that educating means to teach people to learn or relearn something. Changing is necessary, and the act of changing is difficult, modifying old habits occurs gradually and requires constant stimuli, which certainly justifies the inclusion of individuals with DM in continuous monitoring programs ${ }^{(7)}$. Regarding the type of footwear adopted, $100 \%$ used common shoes, and $34 \%$ already had changes in the protective sensation of their feet. This finding corroborated with a study that analyzed the feet evaluation of people with diabetes treated in a health center registered in the Hiperdia program in the state of Pará, where most of the participants used common shoes, despite already having neuropathy and deformities ${ }^{(18)}$. The use of adequate footwear is one of the orientations that health professionals must provide to the person with diabetes. Inadequate shoes are a major cause of ulceration ${ }^{(13)}$. A shoe considered adequate should have thick soles, wide and deep enough to hold an insole and the foot comfortably, the interior of the shoe must be soft and without seams, adjustable with shoelaces or Velcro, offer full protection to the toes (round or square toecap), sole up to three centimeters, and made with soft raw-material ${ }^{(9,12)}$.

Regarding LL skin integrity, the majority had dry skin. and some already had an active ulcer. Autonomic neuropathy causes sudomotor changes, leading to skin dryness, making it necessary to externally lubricate it regularly. Dry skin is susceptible to cracks and, consequently, loses its protective barrier, facilitating the penetration of microorganisms and the development of infections ${ }^{(9)}$. Ulcers also deserve care, because they are considered risk factors for amputations, since $85 \%$ of the amputations performed in people with diabetes are caused by an ulcer ${ }^{(7)}$.

When asked if they would inspect their feet regularly, the majority stated that they did not perform the inspection of those limbs or only performed it sporadically. Feet inspection should be exhaustively recommended for all people with DM, who must be educated and encouraged to adopt the habit to look at their feet regularly and seek help from a health professional if they find any changes such as cracks, maceration, blisters, calluses, ulcers, interdigital mycosis, edema, hyperemia and onychomycosis ${ }^{(6)}$.

Many of the individuals had calluses and callosities, which were considered pre-ulcerative lesions, therefore, predictive of ulcerations. They occur due to musculoskeletal alterations that, associated to insensitive feet, are an important way to ulceration $^{(11)}$. A descriptive study, performed with the objective to characterize people with diabetes in the primary health care network in relation to factors that may trigger diabetic foot, pointed out that the individuals had risk factors for the development of foot complications, such as poor hygiene, cracks, interdigital mycosis, calluses and callosities, toenails trimmed inappropriately and altered protective sensitivity ${ }^{(10)}$. These risk factors can be controlled and modified through a contingency plan to guide, teach and monitor the expected results ${ }^{(7)}$. 
Of the 50 individuals that had their foot examined with the 128 $\mathrm{Hz}$ tuning fork, $28 \%$ had their sensitivity altered. A study conducted in the United States to verify direct medical costs in people with DM due to the reduction of vibratory sensitivity detected that, when this was absent, the expenses were greater, approximately five times more for the treatment of ulcers and amputations when compared with those with normal vibratory sensitivity ${ }^{(19)}$.

The reflex of the Achilles tendon was absent in $40 \%$ of the examined individuals. This number was close to the result of the study that investigated the prevalence sensory-motor DNP in people from the Agreste region in Pernambuco, which found areflexia of the Achilles tendon in $48.3 \%$ of the study participants $^{(20)}$. Tendon areflexia constitutes important musculoskeletal alterations and raises the risk of ulcers in people with $\mathrm{DM}^{(9)}$.

The data from this study showed that the majority of the individuals $(95 \%)$ never had their feet examined with monofilaments. This finding is extremely worrying, because the monofilament is considered the gold standard test to early identify a foot with risk of ulceration. It is a simple, cheap and easily reproducible test. Individuals with DM should have their feet examined at least once a year, and the ones considered at risk should be examined more often ${ }^{(6-7)}$. The individuals examined came from Basic Health Units (BHU), and these units should be provided with the monofilament. Therefore, it is worth asking why $96 \%$ of these individuals have never had their feet examined, that is, are technical capacitation, equipment and professional motivation lacking?, is there excess of work? Finally, it is necessary to raise which are the difficulties faced so that health professionals may have adequate conditions to examine the feet of people with DM habitually. It is noteworthy that examining feet is a valuable form of prevention, and the BHU is part of Basic Health Care, focusing on working on prevention, health promotion and recovery.

Regarding people with posterior tibial and pedis pulses, $12 \%$ had their pulses absent or hard to palpate in the same laterality, suggesting PAD. People with DM above 50 years should have their feet examined, calculating the ABI. If the result of this exam is negative for ischemia (below 1.0), it should be performed every five years, and those with less than 50 years with signs suggesting PAD or with identified risk factors, such as smoking, hypertension, hyperlipidemia or having diabetes for more than 10 years, also should have their $\mathrm{ABI}$ calculated. However, individuals with DM may have Monckeberg sclerosis
- thickening of the middle layer of the arteries. So, when the $A B I$ has values above 1.3, it is advisable to calculate the ToeBrachial Index, because it is believed that digital arteries are not as susceptible to the sclerosis process ${ }^{(7,9)}$.

\section{Limitations of the study}

Data collection occurred in order to introduce sampling selection defects as a result of alterations related to the organizational structure, work process and the absence of a hierarchical line of care in the area of DM in the health unit. There were also difficulties physically examine all patients enrolled in the Prevention and Control of Diabetes Program. Thus, this research cannot generalize the assessment of care to the person with diabetes in other realities.

Contributions to the field of nursing, health or public policy This study identifies the gap in the evaluation of risk of complications arising from DM, established to fight chronic diseases in Brazil. To recognize that the number of amputations from this disease is still alarming and, above all, an important indicator that interferes in the costs spent on health care, as well as a social burden to those affected. This research detected problems in the evaluation of feet and the need to implement a referral service with specificity in podiatry destined to early screening and prevention of LL complications in people diagnosed with DM.

\section{CONCLUSION}

The classification of degree of risk for foot ulceration in people with DM in the studied patients was: Degree of risk 1 $(66 \%)$; risk 2 (16\%); risk $3(6 \%)$ and risk $4(12 \%)$, who need periodic evaluations and consultations every 1 to 12 months.

Regarding the predictive risk factors for ulcerations, the absence of physical feet examination stands out, including the evaluation of protective sensation with the $10 \mathrm{~g}$ monofilament, in addition of pre-ulcerative signs, as well as the presence of dermatofunctional changes, which contribute to the emergence of foot ulcers.

The classification of risk of the individuals with DM concerning the danger to develop foot ulcerations is one of the guidelines for managing diabetic feet, which is why nurses must familiarize themselves with this practice and incorporate it into their care routine.

\section{REFERENCES}

1. International Diabetes Federation-IDF. Diabetes Atlas Seventh Edition[Internet]. 2015[cited 2016 Oct 4]. Available from: http:// www.diabetesatlas.org/resources/2015-atlas.html

2. International Diabetes Federation-IDF. Diabetes Atlas Sixth Edition. International Diabetes Federation. 2013.

3. Rathur HM, Boulton AJ. Recent advances in the diagnosis and management of diabetic neuropathy. J Bone Joint Surg[Internet]. 2005[cited 2016 Oct 4];87B(12):1605-10. Available from: http://www.boneandjoint.org.uk/content/jbjsbr/87B/12/1605.full.pdf

4. Boulton AJM. Management of Diabetic Peripheral Neuropathy. Clin Diabetes[Internet]. 2005[cited 2016 Oct 4];23(1):9-15. Available from: http://clinical.diabetesjournals.org/content/diaclin/23/1/9.full.pdf

5. Boulton AJM. Neuropatias Diabéticas. São Paulo: AC Farmacêutica; 2014. 302 p.

6. International Working Group on the Diabetic Foot[DVD]. International Consensus on the Diabetic Foot. International Diabetes 
Federation; 2011.

7. International Working Group on the Diabetic Foot[DVD]. International Consensus on the Diabetic Foot. International Diabetes Federation; 2015.

8. Ochoa-Vigo K, Pace AE. Pé diabético: estratégias para prevenção. Acta Paul Enferm[Internet]. 2005[cited 2016 Oct 4];18(1):100-9. Available from: http://www.scielo.br/pdf/ape/v18n1/a14v18n1

9. Boulton AJM, Armstrong DG, Albert SF, Frykberg RG, Hellman R, Kirkman MS, et al. Comprehensive Foot Examination and Risk Assessment. Diabetes Care[Internet]. 2008[cited 2016 Oct 4];31(8):1679-85. Available from: https://www.ncbi.nlm.nih.gov/pmc/ articles/PMC2494620/

10. Bortoletto MSS, Haddad MCL, Karino ME. Pé diabético, uma avaliação sistematizada. Arq Ciênc Saúde UNIPAR[Internet]. 2009[cited 2016 Oct 4];13(1). Available from: https://cursos.atencaobasica.org.br/sites/default/files/texto_21__pe_diabetico_avaliacao.pdf

11. Pedrosa HC, Leme LAP, Aguiar CSH. Rastreamento do pé em risco de ulceração. In: Pedrosa HC, Vilar L, Boulton AJM. Neuropatias e Pé Diabético. São Paulo: AC Farmacêutica; 2014. p. 158-69.

12. Sociedade Brasileira de Diabetes. Diretrizes da Sociedade Brasileira de Diabetes 2013-2014. São Paulo: AC Farmacêutica; 2014.

13. Bakker K. Diretrizes práticas sobre o tratamento e a prevenção do pé diabético. In: Pedrosa HC, Vilar L, Boulton AJM. Neuropatias e Pé Diabético. São Paulo: AC Farmacêutica; 2014. p. 281-94.

14. Hoppenfeld S. Propedêutica Ortopédica: coluna e extremidades. São Paulo: Atheneu; 2002.

15. Gomes R, Nascimento EF, Araújo FC. Por que os homens buscam menos os serviços de saúde do que as mulheres? as explicações de homens com baixa escolaridade e homens com ensino superior. Cad Saúde Pública[Internet]. 2007[cited 2014 Oct 4];23(3):56574. Available from: http://dx.doi.org/10.1590/S0102-311X2007000300015

16. Grillo MFF, Gorini MIPC. Caracterização de pessoas com Diabetes Mellitus Tipo 2. Rev Bras Enferm[Internet]. 2007 [cited 2016 Oct 4];60(1):49-54. Available from: http://www.scielo.br/pdf/reben/v60n1/a09v60n1.pdf

17. Scheffel RS, Bortolanza D, Weber CS, Costa LA, Canani LH, Santos KG, et al. Prevalência de complicações micro e macrovasculares e de seus fatores de risco em pacientes com diabetes melito do tipo 2 em atendimento ambulatorial. Rev Assoc Med Bras[Internet]. 2004[cited 2014 Oct 4];50(3):263-7. Available from: http://dx.doi.org/10.1590/S0104-42302004000300031

18. Najjar ECA, Najjar JA, Ferreira EAP, Albuquerque LC. Análise dos pés de pacientes diabéticos atendidos em unidade de saúde. Rev Para Med[Internet]. 2009[cited 2013 Oct 4];23(2). Available from: http://files.bvs.br/upload/S/0101-5907/2009/v23n2/a2009.pdf

19. Shearer A, Scuffham P, Gordois A, Oglesby A. Predicted Costs and Outcomes from reduced vibration detection in people with diabetes in the U.S. Diabetes Care[Internet]. 2003[cited 2013 Oct 4];26(8):2305-10. Available from: http://care.diabetesjournals. org/content/26/8/2305.short

20. Lira JRS, Castro AA, Pitta GBB, Figueiredo LFP, Lage VMM, Miranda Jr F. Prevalência de polineuropatia sensitivo-motora nos pés no momento do diagnóstico do diabetes melito. J Vasc Bras 2005;4(1):22-6. 